http://dx.doi.org/10.12775/szhf.2021.020

Rudolf Dupkala

University of Presov, SLovakia

E-MAIL: RUDOLF.DUPKALA@UNIPO.SK

ORCID: 0000-0002-6036-571X

\title{
Philosophy at the Evangelical College in Prešov in the Contexts of European Intellectual Development
}

\begin{abstract}
The leitmotif of the paper is an analysis and interpretation of philosophy at the Evangelical College in Prešov, Slovakia, in the contexts of European intellectual development from the $17^{\text {th }}$ to the $20^{\text {th }}$ century. The research focuses on the response to and reception of Francis Bacon's philosophy in the work of his Prešov follower Ján Bayer, reflections on Kant's aesthetics in the work of the Prešov professor Michal Greguš and the explanation of Nietzsche's immoralism in the work of Jaromír Červenka. The paper emphasises that philosophy at the Evangelical College contributed to the development of spiritual culture in Slovakia and became part of its cultural heritage. According to the author of the paper, the value of philosophy at the Evangelical College in Prešov lies precisely (and above all) in its ability to creatively reinterpret and apply the key concepts of European philosophy into the philosophical systems of Bayer, Greguš and Červenka.
\end{abstract}

Keywords: Evangelical College in Prešov, Jan Bayer, Jaromir Cervenka, Michal Gregus, history of philosophy 
The city of Prešov belongs among those centres of culture and education in Slovakia with the longest and most abundant tradition. The so-called "Prešov School" contributed greatly to the fact, which, in the opinion of several authors, is synonymous with the Evangelical College in Prešov during its entire, over 330 year-long, history.

The leitmotif of the present monograph is the set of issues pertaining to philosophising and philosophy in the history of the Evangelical College in Prešov. The significance of these issues - from the viewpoint of the above tradition - is supported by the fact that, as early as during the initial period of the functioning of the "Prešov School", i.e. the time of Ján Bayer, Izák Caban, and Eliáš Ladiver working there, Prešov rightly deserved the nickname of the "Athens on the Torysa".

Prior to setting up the Evangelical College, the municipal (Latin) school existed in Prešov, of which there a written record exists, dating as far back as the year 1429. ${ }^{1}$ The school - according to J. Rezik and S. Matthaeides - came under the patronage of the local Evangelical Church directly "by appointment of Martin Luther", which is reportedly evidenced by Luther's letter "written in his own hand in Wittenberg, on the second day after Quasimodogeniti (i.e. the first Sunday after Easter - R.D.) in the year 1554". 2

Several researchers into the field of the history of the Prešov College hold the opinion that the biggest debt in the transformation of the original municipal school in Prešov into an Evangelical lyceum or College is owed to J. Bayer, who, as early as 1664, prepared a special project called Regulae scholasticae. Pro Iuventa Evangelica et eorundem Docentibus concinnatae et praesciptae absque Ao (School regulations. For Evangelical youth and their teachers prepared and prescribed).

The above curriculum created a milieu for tuition in three classes for the teaching of philosophy and logic: in the (fourth) class of logicians (Classis Logicorum), the first professor was Eliás Ladiver, in the (third) Classis Philosophorum, i.e. the class of practical philosophy, Izák Caban was the lecturer,

1 Cf. Béla Iványi, “Adatok Eperjes város középkori iskolaügyének történetéhez”, in: Történelmi Tar, ed. András Komáromy (Budapest: A MAGYAR TÖRTÉNELMI TÁRSULAT TULAJDONA, 1911), 68.

2 János Rezik, Samuel Matthaeides, Gymnaziológia. Dejiny gymnázií na Slovensku (Bratislava: Slovenské pedagogické nakladatelstvo, 1971), 280. 
and in the (second) class of physicist-metaphysicians (Classis Physicorum et Metaphysicorum), teaching was provided by the professor Michal Pongracz. For the sake of thoroughness, it should be noted that in the highest, i.e. in the first class (Classis Theologorum cum linguis orientalibus), Samuel Pomarius himself (the first rector of the College) gave lectures. The basic methods and forms of teaching included: explication, repetition, memorising, creative work, declamations, examinations, and disputes. ${ }^{3}$

Ján Bayer (1630-1674), a native of Prešov, studied philosophy at the University in Wittenberg (1653-1659), where he acquired the degree of Master and Adjunct of Philosophy. Here - as witnessed by several researchers - he became acquainted with the opinions of D. Sennert, T. Campanella, F. Bacon, J. A. Comenius, and some other European thinkers, who through their ideational orientation undoubtedly co-formed the character of his own philosophical position. Despite the fact that Bayer's philosophical position is characterised by all of his most significant interpreters as a Slovak version of Baconism, in answer to the question pertaining to the place and time of when this position was formed, researchers have been unable to reach an agreement.

Bayer's Baconist position is fully supported by his basic works: Ostium vel Atrium naturae ichnographice delineatum (Cassoviae 1662) and Filum Labyrinthi vel Cynosura seu Lux mentium universalis (Cassoviae 1663). Since Bayer himself used abbreviated titles to denote these works: Ostium naturae (the anterum of nature) and Lux mentium (the light of thinking), the same abbreviations are employed in the present monograph. In both of the above works, Bayer positively receives and develops the philosophical views of, especially, F. Bacon and J. A. Comenius.

Bayer expressed his references to Bacon's work in a programme-like manner in the so-called "eleventh enlightenment" (Phenomenon XI.) of the 120page long introduction to the work Lux mentium. In Art. 1 and Art. 2 of this "eleventh enlightenment", Bayer writes: "The opportunity to contemplate this new Light of Thinking (Lux mentium) has been offered to us by Francis Bacon of Verulam in the form of two highly significant works, namely On the

3 See for details: József Hörk, Az Eperjesi ev. ker. Collegium Torténete (Košice: NYOMATOTT BERNOVITS GUSZTÁV KÖ- ÉS KÖNYVNYOMDÁJÁBAN, 1986), 22-23. 
Progress of Sciences and the work The New Organon [...] we have started to compare those works of Bacon not with the Holy Scriptures, but with nature, the senses and experience, with practice and the needs of people. We soon saw that this philosophy defines a much higher objective that the one generally spread (i.e. scholastic Aristotelianism - R.D.) and that it directly offers the tools for its achieving".

However, he notes at the same time that even though he found the foundation stones (and bricks) for the constructions of his work (Lux mentium) in the philosophy of Bacon, he did not only stick with that (Baconesque) "building material". In Articles 5, 6 and 7 he claims that he not only "elaborated", but also "reinforced" the "Baconesque building material", so: "if somebody compares The New Organon by the famous Bacon, in which one talks of induction, with our (i.e. Bayer's - R.D.) teaching of induction, he will find it in a completely new form". ${ }^{5}$

We shall attempt to support Bayer's Baconism by his understanding of the sense of philosophy (or science) by the teaching of knowledge and method (i.e. by defining induction), by the teaching of idols, and his relationship to Aristotle (or rather scholastic Aristotelianism), etc.

Bayer, just like Bacon, departed from the Renaissance-humanistic conviction that man is capable of actively interfering in the world in which he lives, that the basic precondition and tool of this interference is human knowledge, that knowledge is power, etc. Here it is obvious that it is not just about having in mind knowledge in the sense of the traditional scholastic contemplation, but it is more the case of possessing knowledge that is both active and practically useful, which is to be contained in new philosophy and science. One may state in this relation that both Bayer and Bacon attempted at the following "so that science and philosophy do not hover in the air, but rather be laid on firm foundations of the generally embracing and well considered experience of experiential practice". ${ }^{\text {" }}$

In accordance with Bacon, Bayer was looking for a "new tool" (a new organon) of building science and philosophy using a new method, logic, etc.

4 Ján Bayer, Filum Labyrinthi vel Cynosura seu Lux mentium universalis (Cassoviae in Hungaria superiore: Typis Marci Severini, 1663), 108-109.

5 Ibidem, 110.

${ }^{6}$ Francis Bacon, Nové organon, transl. Miroslav Zůna (Praha: Svoboda, 1990), 39. 
In doing so, he accepted both Bacon's empirism and his inductionism. However, he definitely did not identify with Bacon's understanding of mathematics - and its place in the "project" of the new science. Bear in mind that Bacon understood mathematics just as an "auxiliary science" of physics or astronomy while Bayer considered it one of the three main disciplines (theology, philosophy, mathematics), which is why he attributed to it a much greater significance".

The new science was to be, in Bayer's opinion, a "knowledge certain", i.e. higher or more perfect than just an opinion (opinio). Knowledge as represented (and offered) by the new science is certainly not to be self-purposeful. It is to follow a "practical side", it is to contribute to "beatitude eternal and earthly", and it is to depart from the evidence, which means that it should lean against induction.

Whether Bayer was or was not more of a tributary, rather than creative, propagandist of Bacon's teaching, it is important to note that Bayer's reflections have remained - even after three hundred years - a kind of a mystery. J. Bodnár noted the same thing by stating: "it is hard to imagine nowadays how, in the conditions of spiritual oppression, amidst war devastation, misery and backwardness, i.e. the conditions in which Bayer was living, he could have (at all) given birth to a project of work, which was to continue in, even surpass, what F. Bacon created in his renowned work Novum Organum".

In the work Lux mentium Bayer reacts to the works of other European thinkers, predominantly those of Aristotle, Tomas Aquinas, Luther, Melanchton, Descartes, Sennert, Commenius, etc. Whereas he clearly rejects Aristotle and Descartes - as we have already shown - he addresses words of appreciation to Luther and Comenius.

He introduces the work of J. A. Comenius (1592-1670) as one of his main sources of ideology and inspiration. In the eleventh enlightenment (phenomenon XI.) of the introduction to the work Lux mentium Bayer writes: "the scriptures of this significant man (Bayer specifically names Comenius' works

7 See for more details: Ján Bayer, "Školské pravidlá. Pre evanjelickú mládež a jej učitelov zostavené a predpísané”, in: Od královstva ducha ku královstvu človeka, ed. Mária Novacká (Bratislava: Tatran, 1986), 422-423.

8 Ján Bodnár, ed., Dejiny filozofického myslenia na Slovensku I (Bratislava: VEDA, 1981), 109. 
Panaugia and A survey of Physics - R.D.) inspired us a lot, especially when we saw that the aim which he had set long ago is almost identical with ours and the means for achieving it are very similar. On the basis of this, we have reassessed our tools in regard to the content of Comenius' Panaugia. We took notice of Comenius' idea of three principles of all bodies, matter, spirit and Moses light, in which our Lux mentium is governed by the principles almost identical with Comenius' mind and Scriptures".

It is a kind of a paradox, since the work Lux mentium contains substantially less of Bayer's reflection and receptions of Comenius' opinions than in his second Prešov treatise Ostium naturae, in which, however, Bayer makes not a single "direct" reference to Comenius. However, the fact remains that Bayer was no doubt influenced by the work of Comenius. Let us consider which of Comenius' opinions are received by Bayer directly, which of them are modified by interpretation, and which of them are rejected.

We assume the Bayer's works reflect Comenius' "pansophistic" understanding of philosophy, according to which: "philosophy may be corrected and improved by putting everything that is and is happening into a harmonic system, consisting of sense data, reason and Scriptures". ${ }^{10}$

In Bayer - just like in Comenius - philosophy is organically interconnected with religion and natural sciences. Philosophy is to initiate and integrate all "true knowledge" and contribute in this manner not only to mastering nature, but - in Comenius' words - "also to correct human mistakes". However Bayer, unlike Comenius, did not develop this philosophy any further. Comenius' opinions on knowledge also occupied a prominent place in Bayer's works. Both Comenius and Bayer link up with Bacon's sensualism and aposteriorism, from which they derive conclusions for their specific variant of gnoseological optimism.

In the spirit of Comenius, Bayer claims, for instance, that the first precondition of true knowledge is sensual appreciation. However, the senses must be "sane" and the object should be known by several of the senses. Reason (intellectus) connects individual sensual impressions into images (imagines)

\footnotetext{
9 Bayer, Filum Labyrinthi vel Cynosura seu Lux mentium universalis, 112-113.

10 Ján A. Komenský, "Přehled fyziky", in: Ján A. Komenský, Vybrané spisy Jana Amose Komenského. Svazek V. (Praha: Státní pedagogické nakladatelství, 1968), 85-86.
} 
of which general notions are formed in thinking. The highest objective of knowledge is science (scientia), i.e. knowledge precise and certain (cognitio rei certa), which is to bring benefit for man. Bayer also accepts Comenius' opinion on the "supernatural way" of knowledge, which is represented by revelation. In the work Lux mentium he notes that "knowledge - finally - comes from God himself, either by internal inspiration or by external revelation". ${ }^{11}$

The most intense reflections of Comenius' pansophistic works may be found in Bayer's concept of so-called "natural philosophy". For the sake of illustration, let us now compare Comenius' and Bayer's understanding of matter, spirit and light.

Matter is - in Comenius' view -a non-living, bodily, heavy, and dark "substance". The spirit is a live, soft "substance", unperceivable by the senses. Light is a visible, movable "substance" penetrating through matter and preparing it for receiving the spirit. Of special interest is Comenius' explication of the term "light", from which his entire so-called "metaphysics of light" is derived.

Comenius thinks of light in several semantic dimensions, departing from the supposition that "God gave light a threefold power: 1 . To spread in any direction and illuminate everything. 2 . To set matter in motion by heat and fire. 3. To make warm and so dilute matter and make it finer... The arrangement and beauty of the whole world comes from light". ${ }^{12}$ A similar characterisation of matter, spirit, and light may be found in Bayer.

In the work Ostium naturae he departs from the primal uncreated, but creating substance, which is represented by God. The created being is the product of God's creativity (created world), whose main principles are matter (natura subiacens), spirit (natura fabricans), and light (natura ministrans).

Bayer "defines" matter on two levels of meaning: 1. the metaphysical meaning, 2. on the physical level. On the metaphysical level, he applies the notion of "material". On the physical level, he defines it by the term "massa". In his work Ostium naturae, Bayer expressed this in the following words: "Massa est principium corporis materiale". ${ }^{13}$ Other constituting principles of a body are spirit and light.

11 Bayer, Filum Labyrinthi vel Cynosura seu Lux mentium universalis, 112-113.

12 Komenský, "Přehled fyziky", 85-86.

13 Ján Bayer, Ostium vel atrium naturae ichnographice delineatum (Cassoviae in Hungaria superiore: Typis Marci Severini, 1662), 34. 
The spirit may be universal (universalis) or particular (particularis). God is a universal spirit. A particular spirit is contained in a body and creates its (own) form.

Bayer understands light (lux $)$ as a "mediator" between matter and spirit. ${ }^{14}$ Apart from the term "lux" he also employs the term "lumen", whereby he probably wanted to make a distinction between light (lux) as a metaphysical factor and light (lumen) as a physical phenomenon. However, Bayer is obviously inconsistent in his endeavour to capture those distinctions of meaning, which is documented by the fact that he employed the term "lux" in several places in both of its meanings. However, just like Comenius, he finally acknowledges that light influences both spirit and matter and is the originator of motion, it enables the appreciation of colours, brings beauty into the world, etc. ${ }^{15}$

From the end of the $17^{\text {th }}$ century, only Ladiver's younger colleagues: J. Schwartz, J. Karlovský and Ž. Karlovský were actively engaged in teaching philosophy at the Evangelical College in Prešov.

Ján Karlovský (1721-1794) and his son, Žigmund (1772-1821), renewed the mode of philosophising at the Evangelical College in Prešov, which, in the second half of the $17^{\text {th }}$ century, was inspired by the most topical concepts of European philosophy of the time. J. Karlovský was a follower and propagandist of the philosophy of C. Wolff (1679-1754), with which he got acquainted during his studies at the universities of Halle and Goettingen. Considering the fact that Wolff was, in several respects, influenced by the opinions of his teacher, G. W. Leibniz (1646-1716), one may assume that Ján Karlovský, through the philosophy of C. Wolff, established contacts with the monadology of G. W. Leibniz. J. Karlovský continued first of all in Wolff's deistic ontology and ethics founded in the Enlightenment. This is documented by his most significant manuscripts Metaphysica and Philosophia moralis seu Ethica.

In just the same manner as Wolff, J. Karlovský defined in his works three parts: 1. Theoretical, i.e. metaphysics (which he further structured into ontology, cosmology, psychology and natural theology), 2. Practical, i.e. ethics,

\footnotetext{
14 Ibidem, 159.

15 Ibidem, 164-223.
} 
3. Introduction to both of the above, i.e. logic. All of the above parts of Karlovskýs works are analysed in detail in T. Münz's pioneering work Philosophy of the Slovak Enlightenment (Bratislava 1961). T. Münz notes, for instance, that Karlovskýs Metaphysics is just a "brief excerpt" from Wolff's six-volume work. It follows further from Münz's interpretation that ontology is - in Karlovskýs opinion - the teaching of being in general. It examines the reasons, principles, and attributes and fashion of everything in existence. The closest relationship probably exists between ontology and cosmology, which Karlovský understands as the teaching of the universe or the world. The world, according to this teaching, "consists" of things existing in space and time. These things are endowed with power, i.e. inertia and dynamics. The nature of things does not change. The world is the only one and since it is a product of God's creativity, it is perfect; therefore, the product of what is "perfect" cannot be anything imperfect. Considering the fact that the world was "created", it cannot be eternal. Münz characterises Karlovskýs words as a compromise between the teaching of modern physics, which tended to explain natural occurrences only from nature itself and limit any interventions into it from the supernatural to the least possible measure and between the traditional Christian opinion of the creation of the world 'out of nothing' and of God's administrating of it. All in all, physics does provide the most convincing picture of the world, "since", as Karlovský points out, "if God has not added to nor subtracted anything from the world ever since He created it and the world has been running from the beginning under the laws defined by His unchangeable will $[\ldots]$ God did not change nature [...] prayers to Him were useless $[\ldots]$ etc.." ${ }^{16}$

The European context of philosophising at the Evangelical College in Prešov was developed by the immediate follower of Ž. Karlovský, Michal Greguš (1793-1838). M. Greguš worked at the College from the year 1817 to the year 1832 and during the year 1831-1832 he held the post of headmaster. Apart from philosophy, he lectured in history, mathematics, physics, and, mainly, in aesthetics. He acquired professional education in philosophy at the universities of Tuebingen, Goettingen and Heidelberg. There, he familiarised himself with the thoughts of I. Kant, J. F. Fries, K. L. Reinhold, J. W. Goethe,

16 Teodor Münz, Filozofia slovenského osvietenstva (Bratislava: VEDA, 1961), 206. 
F. Schiller, J. G. Fichte, F. Bouterwek, W. T. Krug and other German authors. Most probably, the greatest influence on the young Greguš was exerted by his Goettingen professor, F. Bouterwek, who mediated for him not only his own concept of aesthetics, but also the "re-valuated" philosophy of I. Kant.

From an abundance of works by M. Greguš, the most worthy of mentioning here are his Logic (1833), written in Latin, Metaphysics (1834), Practical Philosophy (1835), and especially his famous Compendium to Aesthetics (Compendium Aestheticae), which - having been the first textbook on aesthetics published in this country in book form - appeared in Košice in the year 1826.

Greguš deserves major recognition for the development of philosophising and philosophy at the Evangelical College in Prešov due to his theoretically well-founded concept of aesthetics. It is J. Sošková, who systematically and in detail analyses the above issues within contemporary Slovak philosophy and who states that (originally) "Michal Greguš considered his Compendium an informational and pedagogical-instructive treatise meant as an aid to students, but despite that we may consider it the first systematic aesthetics in this country from an author living here, in which modern European aesthetics thinking is presented". ${ }^{17}$

Gregušs treatise Compendium Aestheticae contains a foreword, six introductory paragraphs, and two main parts. In the introductory paragraphs, he defines the notions of "aesthetics", he characterises aesthetics as scholarship with a special object of research, he delineates its terminological apparatus, classification and its brief history.

The first part is called General Aesthetics and Greguš classifies it into five sections, in which he, in 47 paragraphs, explains the idea of beauty, analyses the notions of charm and grandeur, considers aesthetic taste, aesthetic judgement, and the like.

The second part is called Special Aesthetics and the author divided it into three sub-sections, four headings, and 34 paragraphs. Its leitmotif is the set of issues concerning the liberal arts (the arts absolutely beautiful and the arts relatively beautiful. Painting, sculpting, tonic or musical arts, mimic arts, verbal arts, poetry and prose as verbal arts, etc.).

\footnotetext{
17 Jana Sošková, Estetika Michala Greguša (Prešov: Filozofická fakulta PU, 1998), 17.
} 
We have already stated that Greguš, due to his work, Compendium Aestheticae, maintained relationships with the most topical philosophical and aesthetic concepts of Western European provenance. He himself comments on this by saying that "he repeated too many such things, which had been said by others, but he did not conceal the sources, from which he was drawing". ${ }^{18}$. The truthfulness of his words is supported mainly by paragraph 6 of the analysed work Compendium Aestheticae, in which he introduces as his "sources" the following works: I. Kant's Kritik der Urteilskraft, K. H. Heydenreich's System der Aesthetik, J. A. Ebehard's Handbuch der Aesthetik fuer gebildete Lehrer aus allen Standen, A. Batteux's Les beaux arts a un meme principe, H. Home's Elements of Criticism, F. Bouterwerk's Aesthetik, W. T. Krug's Aesthetik. ${ }^{19}$

Greguš, as has already been pointed out by Sošková, was the one who most extensively "exploited" the German resources of the time, especially the works by I. Kant, F. Bouterwek, and W. Krug. This is documented by Gregušs definition of aesthetics as a science, which had been, in Soškovás opinion, inspired by Bouterwerk's works Geschichte der schoenen Wissenschaften (1801) and Aesthehik (1806) and by Krug's books Versuch einer systematischen Encyklopedie der schoenen Keunste (1802) and Handbuch der Philosophie (1820).

In the first paragraph of his work, Compendium Aestheticae, Greguš states that aesthetics "may be defined as the science of the beautiful". ${ }^{20}$ Since aesthetics is philosophically capable of also explaining the idea of absolute beauty, it may be, in Gregušs opinion, considered a science, which is "very close to philosophy". ${ }^{21}$

Without paying any regard to Gregušs ties to Kant, Krug or Bouterwerk, the fact remains that Greguš was able to think independently and creatively, the evidence of which is the above analysed Compendium Aestheticae. The publication of this work in Slovakia in the $1^{\text {st }}$ third of the $19^{\text {th }}$ century was undoubtedly an editorial achievement. The above work illustrated not only the outstanding gifts and mastery of its author, but also the fact that the professors

18 Michal Greguš, "Rukovät estetiky”, in: Antologie $z$ dějin českého a slovenského filosofického myšlení (do roku 1848), ed. Jarmila Oborská, Ivana Štekrová (Praha: Svoboda, 1981), 318.

19 Cf. Michal Greguš, "Rukovät estetiky", in: Kapitoly k dejinám estetiky na Slovensku, ed. Ján Gbúr, Jana Sošková (Prešov: Prešovská univerzita, 1998), 201.

${ }^{20}$ Greguš, "Rukovät' estetiky”, 318.

${ }^{21}$ Ibidem, 320. 
of the Prešov Evangelical College had not lost touch with the Western European thinking of the time.

After the rise of the First Czechoslovak Republic (in the year 1918), substantial changes occurred in the organisational structure of the Prešov College. From among the original organisational constituents of the College, only the eight-year College Gymnasium and the Evangelical Teacher Training Institute were preserved (Both the Academy of Theology and the Academy of Law ceased to operate within the framework of the College in the year 1919). When, in the year 1924, the college's Teacher Training Institute "merged" with the state-run Girls' Teacher Training Institute, having in this way formed The State Czechoslovak Co-educational Teacher Training Institute, the "slovakised" Evangelical College Gymnasium remained the only educational establishment of the College .

Despite the fact that the Prešov College - due to the above reorganisation - lost its character, which in the past had "drawn it near" to a university, the teaching of philosophy achieved here, even under the altered conditions, a relatively high level. This was to the credit of professors Jozef Koreň, Stanislav Treybal, Jaromír Červenka, Stanislav Felber and Ján Mikleš.

Jaromír Červenka (1903-1988) was a graduate from Charles University. He worked at the Prešov College in the years 1939-1940 as professor of Latin, Greek, and philosophy (previously, i.e. from the year 1926 until the year 1939, he was a teacher at secondary schools in Košice). "Even though he spent a short time as a teacher at the College - he had to leave Slovakia in the year 1940 because he was a Czech - he has left a remarkable trace in the history of Slovak science".22 According to the personal testimony of Ján Mikleš, who was his close colleague at the Prešov College Gymnasium, Červenka "was a very industrious man. He was responsible in his preparation for classes. He knew how to make suitable marginalia for explaining Latin and Greek texts. I can still remember his small letters of marginal remarks, which

${ }^{22}$ Andrej Čuma, Mária Podhájecká, "Vedecko-pedagogický profil Jaromíra Červenku a Jána Mikleša”, in: Prešovské evanjelické kolégium, jeho miesto a význam v kultúrnych dejinách strednej Európy, ed. Peter Kónya, René Matlovič (Prešov: Biskupský úrad východného dištriktu ECAV na Slovensku, 1997), 181. 
Červenka was adding to the texts. These are good teachers, who so diligently prepare for each class". 23

Červenka introduced several new themes into philosophising at the College (and in Slovakia as a whole). This is documented by his "Prešov works", of which special attention should be paid to his most extensive studies: Merits of Stoics in Logic and The Prešov Evangelical College in the History of Philosophy. Several other studies pertained quite considerably to his sojourn in Prešov: Friedrich Nietzsche, Aristotle, and the Thinkers of the Reformation in the $16^{\text {th }}$ and $17^{\text {th }}$ Centuries, although he published these after his departure from Prešov.

Analogically, his reflections on Nietzsche's philosophy are related to the sojourn and work of Červenka in Prešov, and was published in Prague in the year 1942 as a monograph. While in Prešov, Červenka was especially interested in the issue of Nietzsche's immoralism, under which he understands the position or the concept rejecting morality completely (i.e. the synonym for non-morality or non-morals), but presents it as "criticism of [the] existing morals and manner of creating new moral values", ${ }^{24}$ of which Nietzsche is, in Červenka's opinion, convinced that they will be "higher" (i.e. more valuable) than the existing ones.

One of the most decisive ideational sources of Nietzsche's immoralism is considered, by Červenka, to be the idea of the relative character of moral standards and subsequent thoughts on double morals developed as early as the period of Greek pre-Socratic philosophy, even on the level of Greek mythology, while the chief protagonists of those ideas are Homer, Hesiodes, Heracleitos, Protagoras and Gorgias.

Červenka examines Nietzsche’s immoralism against the background of an analysis of his overall philosophical developments, in which he distinguishes three basic periods: 1. Romantic, 2. Positivistic, 3. Constructive.

In the first period, Nietzsche's immoralism is manifested - according to Červenka - only in indications. He concentrates on philological issues. The ideal type of man is, for him, a genius of arts. He expressed a more principled

${ }^{23}$ Quoted according to Kamil Rác, "Pred 25 rokmi zomrel Jozef Koreň", Filozofia 49 (1994).

${ }^{24}$ Jaromír Červenka, Friedrich Nietzsche: studie o jeho imoralismu a jeho predzvěstech $v$ řecké filosofii (Praha: Česká grafická unie, 1942), 9. 
standpoint on the issues of morals at that time only in the unpublished texts for the prepared treatises Homer's Wettkampf and Der letzte Philosoph. Červenka notes that "in Nietzsche's works of that time we not only recognise the science of the future ethical theory, but also a preliminary image of his superman". ${ }^{25}$ At the same time, however, he emphasises that his ethical conception obtains a more comprehensive form in his second period, which is opened by the work Human, Too Human. Červenka claims that Nietzsche resigns from his original artistic romantic aims. He contemplated on morals especially, to which the newly asked questions of man, humankind, society, history and the like was related. Červenka notes that it is not coincidental that, in the treatise Human, Too Human, for the first time, emerge expressions like uebermenschlich, uebermenschlichkeit, immorality and once even the word Uebermensch. ${ }^{26}$ Nietzsche declares the morals existing at that time to be a swindle, he holds it responsible for all human weakness and misery, since morals "by [its] cowardly values suppress[es] what is the best in man" and makes him an "obedient herd animal". Despite the fact that, in that period, Nietzsche devoted himself predominantly to criticism of existing morals, one can recognise in his works an endeavour to create new values. The genius of arts ceases to be an ideal of man, the ideal is now becoming a man of science.

In Červenka's view, the third period starts with the work Thus Spoke Zarathustra. Nietzsche's immoralism reaches its culmination in that period. Reevaluation of values does not only have a character of pure negation, but is connected with the presentation of new values. These values become the point of departure of new morals, the creator and bearer of which is a new type of man, i.e. by Zarathustra, declared superman. Apart from that, the idea of eternal return is propagated in that period, from which it follows that all acting in the world goes in circles and all of the events repeat themselves after certain time intervals.

The outlined development of Nietzsche's immoralism is summarised by Červenka as follows: "I attempted to show that the beginnings of Nietzsche's immoralism fall within the period when he himself did not know that one

25 Ibidem, 34.
26 Ibidem, 49. 
time he would deal with moral issues... From occasional and sometimes coincidental notes and ideas which appeared here and there in his older works, grew, in the second period, into the main issue of his work. We find the final solution to this problem in his works of the third period. From then on, we may reconstruct his whole ethical system based on the principles that any moral values are relative, that today's evaluation has serious shortcomings, since it supports the weak and oppresses the strong, that a change of evaluation is not only inevitable of strong individuals, but in the interests of humankind as such, that new ethical principles may be personified by a higher man, i.e. superman". ${ }^{27}$

J. Červenka then reflects on the works of Nietzsche exclusively through the prism, or semantic field, of his immoralism. Although he realises that Nietzsche's immoralism contains several negative aspects, including its possible culmination in the reasoning of the laws of the jungle and barbarically imposing the rule of the strong over the weak, he emphasises that despite "[not] hav[ing] to sympathise with the dauntlessness with which Nietzsche was preaching his principles and bravery with which he managed to stand against the steam of current opinions". ${ }^{28}$ In this regard, he compares him to pre-Socratian philosophers, who, just like him, had to bear the burden of misunderstanding and loneliness. He notes that his immoralism should only be understood as an academic debate, which in modern philosophy ranks among the most original ethical concepts, whereby he finally excuses himself in a certain way. We may discuss Červenka's attitude towards this, however, it was not (and is not) our primary objective.

Červenka should be, in our opinion, specifically credited for his qualified explanation of the ancient inspirations of Nietzsche's immoralism, where he was the first in this country to have pinpointed the inspirations which Nietzsche was drawing from the Sophists; Theogonis and Theodoros from Kyrena. His reflections on Nietzsche's philosophy is characterised by a clear style and testifies to the fact that he was precise in orientating himself not only in the work of Nietzsche, but in the entire - then topical - interpretational literature.

\footnotetext{
27 Ibidem, 130-131.

28 Ibidem, 259.
} 
It follows from the development of philosophising and philosophy at the Evangelical College in Prešov as delineated above that, from the $2^{\text {nd }}$ half of the $17^{\text {th }}$ century until the $1^{\text {st }}$ half of the $20^{\text {th }}$ century, here - in teaching philosophy - practically all of the basic philosophical branches were developed; that is ontology, gnoseology, logic, anthropology, ethics, aesthetics, and the first concepts of the history of philosophy were indicated.

Philosophising at the Evangelical College in Prešov was certainly not only of Epigonic or plagiaristic character. The fact remains that Prešov professors of philosophy were following the steps of their European teachers or models, this however, does not mean that they were walking in the latter's footsteps with their eyes closed. They were paying respect to philosophical or theological authorities, but at the same time they managed to think independently. In many respects, they were tributary, i.e. not original, but they certainly were not unproductive. They were characterised by their ability to re-interpret things creatively, to modify and apply them.

From this viewpoint we may say, alongside with J. Bodnár, that the Evangelical College in Prešov or, put it in other words, "the Prešov School", is in a certain sense, indeed, a "unique occurrence in the development of philosophical thinking in Slovakia". ${ }^{29}$ The ideational legacy, which has been left to us by the College, represents a permanent and dignified constituent of the spiritual culture of the Slovak nation. Even after time had elapsed, the most precious jewels of the legacy are represented by the "lux mentium", the light of thought.

The College established in Prešov the tradition of academic education, to which even the academic institutions active in this city today may proudly avow them, since the value of education is timeless.

\section{References}

Bacon Francis. 1990. Nové Organon, transl. Miroslav Zůna. Praha: Svoboda.

Bayer Ján. 1662. Ostium vel Atrium naturae ichnographice delineatum. Cassoviae in Hungaria superiore: Typis Marci Severini.

29 Ján Bodnár, Dedičstvo myšlienok: (Z dejín filozofického myslenia na Slovensku) (Bratislava: Smena, 1983), 58. 
Bayer Ján. 1663. Filum Labyrinthi vel Cynosura seu Lux mentium universalis. Cassoviae in Hungaria superiore: Typis Marci Severini.

Bayer Ján. 1986. "Školské pravidlá. Pre evanjelickú mládež a jej učitel’ov zostavené a predpísané”. In: Od královstva ducha ku královstvu človeka, ed. Mária Novacká. Bratislava: Tatran.

Bodnár Ján, ed. 1981. Dejiny filozofického myslenia na Slovensku I. Bratislava: VEDA. Bodnár Ján. 1983. Dedičstvo myšlienok: (Z dejín filozofického myslenia na Slovensku). Bratislava: Smena.

Červenka Jaromír. 1942. Friedrich Nietzsche: studie o jeho imoralismu a jeho předzvěstech v řecké filosofii. Praha: Česká grafická unie.

Čuma Andrej, Mária Podhájecká. 1997. "Vedecko-pedagogický profil Jaromíra Červenku a Jána Mikleša". In: Prešovské evanjelické kolégium, jeho miesto a význam v kultúrnych dejinách strednej Európy, ed. Peter Kónya, René Matlovič, 181-189. Prešov: Biskupský úrad východného dištriktu ECAV na Slovensku.

Greguš Michal. 1981. "Rukovät estetiky". In: Antologie $z$ dějin českého a slovenského filosofického myšlení (do roku 1848), ed. Jarmila Oborská, Ivana Štekrová. Praha: Svoboda.

Greguš Michal. 1998. "Rukovät estetiky". In: Kapitoly k dejinám estetiky na Slovensku, ed. Ján Gbúr, Jana Sošková, 155-204. Prešov: Prešovská univerzita.

Hörk József. 1986. Az Eperjesi ev. ker. Collegium Torténete. Košice: NYOMATOTT BERNOVITS GUSZTÁV KÖ- ÉS KÖNYVNYOMDÁJÁBAN.

Iványi Béla. 1911. "Adatok Eperjes város középkori iskolaügyének történetéhez". In: Történelmi Tar, ed. András Komáromy, 67-88). Budapest: A MAGYAR TÖRTÉNELMI TÁRSULAT TULAJDONA.

Komenský Ján A. 1968. "Přehled fyziky". In: Ján A. Komenský, Vybrané spisy Jana Amose Komenského. Svazek V. Praha: Státní pedagogické nakladatelství.

Münz Teodor. 1961. Filozofia slovenského osvietenstva. Bratislava: VEDA.

Rác Kamil. 1994. "Pred 25 rokmi zomrel Jozef Koreň”. Filozofia 49.

Rezik János, Samuel Matthaeides. 1971. Gymnaziológia. Dejiny gymnázií na Slovensku. Bratislava: Slovenské pedagogické nakladatelstvo.

Sošková Jana. 1998. Estetika Michala Greguša. Prešov: Filozofická fakulta PU. 